\title{
Macrobenthic Community Structure in a Transplanted Eelgrass (Zostera marina) Meadow
}

\author{
Jurij Homziak ${ }^{1}$, Mark S. Fonseca ${ }^{2}$ and W. Judson Kenworthy ${ }^{2}$ \\ ${ }^{1}$ University of North Carolina, Curriculum in Marine Sciences, Chapel Hill, North Carolina 27514 and Institute of Marine \\ Sciences, Morehead City, North Carolina 28557, USA
}

2 National Marine Fisheries Service, NOAA, Southeast Fisheries Center, Beaufort Laboratory, Beaufort, North Carolina 28516, USA

\begin{abstract}
A 203-d survey of eelgrass macrofauna was conducted in an experimental eelgrass transplant which developed different degrees of macrophyte cover. This is the first study of a benthic macrofaunal community in a transplanted seagrass meadow; it demonstrates the effect of seagrass on macrofaunal density, species abundance, diversity, and dominance. Species composition and numerical dominants varied with season during the experiment, with decreasing affinities between the fauna of the developing seagrass meadow and the unvegetated controls. Various polychaete species were the numerical dominants throughout the experiment. Both time and density of eelgrass significantly affected the 4 community parameters measured. Species composition, numerical abundance, number of species, species diversity, and dominance were similar among all treatment and control plots before transplanting eelgrass. These parameters increased linearly in the unvegetated control plots from October 1978 to May 1979. Macrofaunal density, number of species and diversity responded positively but non-linearly to increasing eelgrass shoot density in the developing meadow. Dominance decreased nonlinearly with increased shoot density. Shoot density appeared to be a major factor regulating the structure of the developing eelgrass community.
\end{abstract}

\section{INTRODUCTION}

Various species of seagrass are among the most productive ecosystems in the world (Wood et al., 1969; Phillips, 1974a; Thayer et al., 1975a; Zieman and Wetzel, 1980). The single most important temperate species is the eelgrass Zostera marina L. Seagrass beds support a rich fauna including fishes (e.g. Adams 1976; Orth and Heck, 1980) and invertebrates (e.g. Orth, 1973; Rasmussen, 1973; Thayer et al., 1975b; Thayer and Phillips, 1977). Many species in eelgrass beds are of importance to commercial and recreational fisheries (e.g. Kikuchi, 1974; Thayer and Stuart, 1974; Heck and Orth, 1980; Orth and Heck, 1980).

While the contribution made by eelgrass to the overall primary productivity of estuarine and coastal waters was recognized over a half century ago (e.g. Petersen, 1918), its complex organizational role in coastal ecosystems has only recently been recognized (Thayer et al., 1975a; Thayer and Phillips, 1977; Phillips and McRoy, 1980). Beds of eelgrass modify the benthic environment by altering local chemical (McRoy, 1974.
McRoy and Goering, 1974; Phillips, 1974a; Kenworthy, 1981) and physical (Marshall and Lukas, 1970; Wayne, 1974; Orth, 1975, 1977; Fonseca, 1981; Kenworthy, 1981) conditions. The high productivity of eelgrass and its epiphytes (Penhale, 1977), plus its influence on the environment, strongly influences the structure and function of the associated benthic communities (Phillips, 1974a; Thayer and Phillips, 1977; Thayer et al., 1975a, b; Orth, 1977).

Natural disturbances, such as scour and sedimentation associated with hurricanes (Orth, 1974), foraging activities of benthic feeding fishes (Orth, 1975), or disease (Johnson, 1964; Rasmussen, 1973) may reduce or destroy eelgrass locally or over a wide area. Man's destructive activities, such as dredging and filling, and discharge of heated wastewater and domestic and industrial sewage, often adversely affect eelgrass stocks (Linton and Cooper, 1971; Thayer et al., 1975a; Lindall et al., 1979). The damage resulting from these or from natural perturbations may have persistent and far-reaching consequences.

Transplanting by various methods (Phillips, 1974b) 
has been used to revegetate damaged seagrass meadows and to create new ones. The overall objective has not been simply to establish vegetation or to stabilize sediments but to create or re-establish a functioning eelgrass community (sensu Kikuchi and Pérès, 1977). Unfortunately, reports have tended to overlook this objective and have concentrated instead on limited aspects of the transplant, such as eelgrass phenology (Ranwell et al., 1974; Phillips, 1976; Kenworthy and Fonseca, 1977), sediment effects (Churchill et al., 1978), or transplanting methodology (Phillips, 1974b; Robilliard and Porter, 1976). Emphasizing specific aspects is worthwhile, but we believe that an integrated, multi-disciplinary study of seagrass transplants including evaluations of water column and sediment effects, changes in macroinvertebrate community structure, and seagrass population dynamics and phenology is necessary to evaluate accurately transplanting techniques or transplanting success.

Development and succession of seagrass associated benthic communities may also be studied in transplanted grassbeds. Concepts of the role that seagrasses play in structuring marine benthic communities are based largely on 'natural experiments' (Connell, 1974), such as simultaneous comparisons of vegetated and unvegetated areas (O'Gower and Wacasey, 1967; Santos and Simon, 1974; Stoner, 1980) and on observations of natural destruction (Dexter, 1944; Rasmussen, 1973; Orth, 1975) or revegetation (Dexter, 1950; Thayer et al., 1975a) of seagrass beds. Manipulative experimental studies, such as denudation experiments (Marshall and Lukas, 1970; Orth, 1977; Young and Young, 1978) or the use of artificial grasses (Wayne, 1974), have made a much smaller contribution. This manipulative approach needs to be developed further and should include the planting as well as the removal of seagrasses in the study of seagrass associated macrobenthic communities.

Recently we studied the development of a transplanted grassbed system by simultaneously evaluating the growth, reproduction, and productivity of eelgrass, changes in physical and chemical parameters, and changes in benthic macrofauna (Fonseca et al., 1979; Kenworthy et al., 1980). In this paper we compare macrofaunal density, number of species, diversity, dominance, and species composition between revegetated areas and unvegetated controls.

\section{STUDY AREA}

The transplant site was located in Middle Marsh, a shallow embayment (approximately $35 \mathrm{~cm}$ depth MLW) that is part of a Spartina alterniflora marsh in Back Sound, Carteret County, North Carolina - an area described in detail by Kenworthy (1981) and defined by Brett (1963) as a 'marsh island lagoon environment'. During the winter of $1977 / 78$, we observed that scallop dredges had uprooted most of the seagrass. Repeated observations by us revealed little or no regrowth of vegetation by September, 1978. This extensive disturbed area (approximately $3.5 \mathrm{ha}$ ), which historically supported extensive seagrass meadows, provided a suitable location for the reestablishment of an eelgrass meadow

\section{METHODS AND MATERIALS}

\section{Transplant Experiment}

At the experimental site, 14 treatment plots $(6 \times 6 \mathrm{~m})$ were established. Ten plots were replicates of 5 planting treatments, 2 were planting controls, and 2 were untreated controls. We planted both, eelgrass Zostera marina and shoal grass Halodule wrightii.

The transplant experiment was designed to evaluate 3 factors. First, we tested the hypothesis proposed by Kenworthy and Fonseca (1977) that Zostera marina stock originating from different current regimes may exhibit different rates of revegetation and that $Z$. marina stock collected from high current areas would develop the greatest degree of cover in the shortest time. We designated 2 treatments, high energy $Z$. marina (HEZ) and low energy $Z$. marina (LEZ), using high and low current energy stock, respectively, to test this hypothesis. Second, we tested the feasibility of transplanting shoal grass Halodule wrightii (treatment

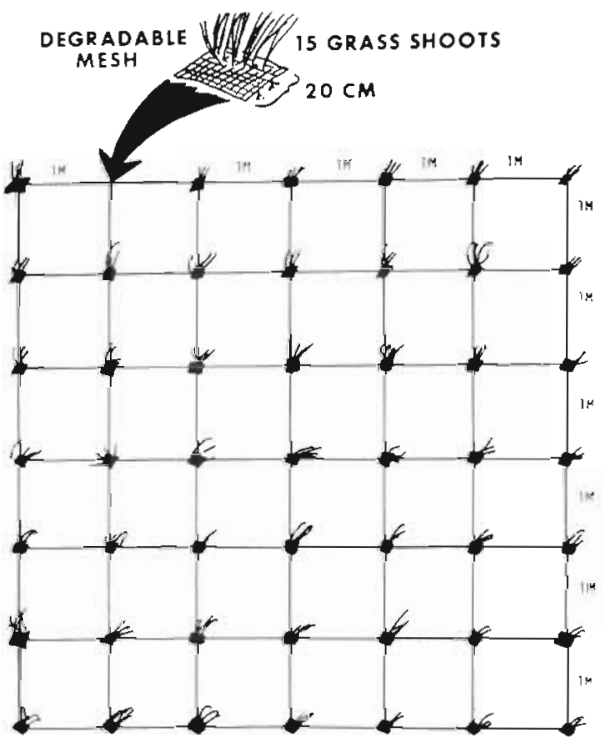

Fig. 1. Planting layout of a treatment replicate. Fifteen shoots are woven into a $20 \times 20 \mathrm{~cm}$ mesh. Meshes are then planted on $1 \mathrm{~m}^{2}$ centers in a $6 \mathrm{~m} \times 6 \mathrm{~m}$ grid 
HAL), a tropical species at the northern limit of its range in North Carolina (Phillips and McRoy, 1980). Third, we wanted to determine if mixed $Z$. marina $-H$. wrightii plantings, which could theoretically survive a wide range of temperature and salinity variations, would succeed in this area. We employed both energy regime stocks of $Z$. marina in mixed plantings with $H$. wrightii. Treatments HEX and LEX were high energy and low energy mixed species plantings, respecitvely

Seagrass shoots, washed free of sediment, were woven into $20 \times 20 \mathrm{~cm}$ paper and plastic meshes at 15 shoots per mesh (Fig. 1). A total of 49 meshes were emplaced by divers in each replicate $6 \times 6 \mathrm{~m}$ treatment plot. Meshes were anchored by steel pins to the sediment at $1 \mathrm{~m}$ centers in all 5 planting treatments. The entire transplant was accomplished within $24 \mathrm{~h}$. For the planting control (CON), meshes devoid of shoots were used. Two undisturbed $6 \times 6 \mathrm{~m}$ plots served as experimental control (OS). A more detailed description of planting treatments and methods is provided by Fonseca et al. (1979).

\section{Monitoring the Transplant}

Plant and invertebrate samples were collected from the transplant 4 times: in October, 1 wk before the start of the experiment, $27 \mathrm{~d}$ after planting (November), $127 \mathrm{~d}$ after planting (February), and $203 \mathrm{~d}$ after planting (May). We estimated seagrass density in each treatment replicate by counting all grass shoots at 5 randomly selected planting meshes in the planting grid. We estimated grass density in the controls by counting the number of shoots in $5 \mathrm{~lm}^{2}$ quadrats randomly placed in the control plots. We located planting meshes and sampling quadrats by drawing pairs of random numbers to determine coordinates within the planting grids.

Benthic macrofauna were collected with a hand-held aluminum core $\left(380 \mathrm{~cm}^{2}\right.$ area) to a depth of $35 \mathrm{~cm}$. We arbitrarily selected this depth in an effort to include deeper dwelling forms such as Tagelus and arabellid polychaetes, which are often missed by shallower cores, and to penetrate the root and rhizome system of eelgrass, which normally extends to at least $20 \mathrm{~cm}$. Core sampling, while intended to collect infaunal organisms, also tended to include epifaunal and seagrass associated epiphytic organisms. While these groups did appear in the samples, noticeable numbers of seagrass-associated forms, such as gammarid amphipods and gastropod species, did not appear in the collections until the May samples. Even then this group comprised only a small percentage of the total abundance and species richness of the collection. Two replicate large area cores $\left(380 \mathrm{~cm}^{2}\right)$ were found to sample adequately macrobenthic invertebrate populations. Downing (1979) relates sample area and the number of replicates required in a benthic sampling program. By increasing the area of each replicate core we reduced the number of cores needed to sample adequately macroinvertebrate populations.

Following collection, cores were stored in plastic bags and returned to the laboratory. Cores were then sieved through an $0.5 \mathrm{~mm}$ mesh screen (Lewis and Stoner, 1980) and the residue was treated $7 \% \mathrm{MgCl}_{2}$ dissolved in tap water to narcotize the annelids and facilitate identification (Fauchald, 1977). Following narcotization we fixed the residue in $10 \%$ Formalin in seawater to which approximately $100 \mathrm{mg}^{-1}$ of rose bengal had been added (Mason and Yevich, 1967). The stained residue was sorted at a later date. All recovered organisms were identified to species if possible.

Four aspects of the benthic community were evaluated in each sample: total number of individuals (N), total number of taxa (S), an index of dominance (DI) (McNaughton, 1967), and species diversity by the Shannon-Weaver index

$$
H^{\prime}=-\Sigma p_{i} l n p_{i}
$$

where $p_{i}=$ proportion of numbers the $i_{\text {th }}$ species makes up of the sample total; $S=$ number of species present.

We compared mean macrofaunal density, number of species, and species diversity between treatments in the pre-planting samples by one-way ANOVA to test for similarity in these parameters among treatment plots (Orth, 1977). We used a $7 \times 2$ areas-by-times factorial ANOVA for an overall comparison of $N, S$, and $H^{\prime}$ by treatment and before and after planting when variances, tested by F-max test (Sokal and Rohlf, 1969), proved to be homogeneous. Where we noted main effects to be significant, Duncan's Multiple Range Test (Steel and Torrie, 1960) was used to make multiple comparisons between sample means. Similarities of species composition between treat ments, both before planting and at the end of the experiment, were estimated by calculating an index of faunal affinity (Sanders, 1960). While this index is biased due to its relation to sample diversity (Murdoch et al., 1972), it does permit quantitative comparisons and allowed us to compare our results with those of other studies (e.g. Orth, 1973, 1977; Cammen, 1976).

To determine if observed changes in the community parameters, $N, S$, and $H^{\prime}$ and $D I$, were related to developing macrophyte cover or time, we regressed these parameters on blade density and calculated a coefficient of determination. Two sets of regression lines were developed. In one, we related parameter values to the degree of macrophyte cover without considering seasons. In the other, we first grouped the 
treatments into vegetated and unvegetated plots and then regressed community parameters on time for each of the 2 groups. We defined vegetated plots as those where areal cover of eelgrass exceeded $10 \%$ of the total area within the plots by the end of the monitoring period. These treatments included HEZ, LEZ, and LEX. Treatments with less than $10 \%$ cover were designated unvegetated and included treatments HAL, CON, and OS. Treatment HEX was not included in these regressions.

\section{RESULTS}

Significant cover of eelgrass developed in most transplant treatments (Fig. 2). All planting treatments lost some transplanted shoots during the first $27 \mathrm{~d}$. In the subsequent sampling periods all treatments, except the high energy stock Zostera marina Halodule wrightii mixed plantings (HEX), showed marked increases in shoot density. Shoal grass (treatment HAL) was not successfully transplanted. Both low current energy eelgrass plantings, treatments LEZ and LEX developed similar shoot densities by the end of the experiment even though LEX, a mixed species planting, was started with only half of the shoot density of the LEZ plots.

Treatment HEX (high energy Zostera marina Haladule wrightii mixed planting) developed sparse and patchy growth due in part to the failure of shoal grass to root and to an unusually high number of missing meshes (see Fonseca et al., 1979, for complete discussion of transplant results). We excluded the results of this treatment from most further analyses.

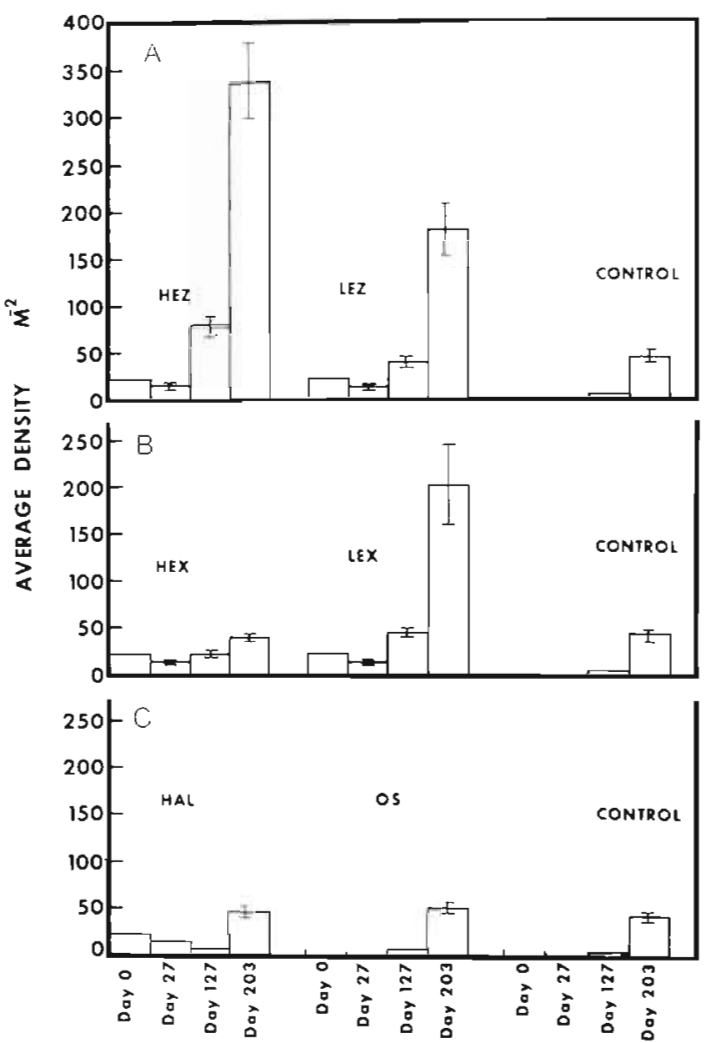

Fig. 2. Average shoot density $\left(\mathrm{m}^{-2}\right)$ of Zostera marina at each sampling period for each treatment. Bars \pm 1 standard error. Where no error bars are noted, there was either no error in counts (Day 0) or error bars were too small to be resolved. HEZ (High Energy Zostera marina), LEZ (low Engergy $Z$. marina), HEX (High Enery $Z$. marina in Mix with Halodule wrightil), LEX (Low Energy $Z$. marina in mix with $H$. wrightii), HAL (H. wrightii)

Table 1. Dominant taxa, those contributing $10 \%$ or more to numerical abundance, for each sample date, with the $\%$ contribution of each taxon

\begin{tabular}{|c|c|c|c|c|}
\hline \multirow[t]{2}{*}{$\begin{array}{l}\text { Sample } \\
\text { date }\end{array}$} & \multicolumn{2}{|l|}{$\begin{array}{l}\text { Vegetated treatments } \\
\text { (HEZ, LEZ, LEX) }\end{array}$} & \multicolumn{2}{|l|}{$\begin{array}{l}\text { Unvegetated treatments } \\
\text { (HAL, CON, OS) }\end{array}$} \\
\hline & Dominant taxa & $\begin{array}{l}\% \text { of } \\
\text { total } N\end{array}$ & Dominant taxa & $\begin{array}{l}\% \text { of } \\
\text { total } N\end{array}$ \\
\hline Day 0 & $\begin{array}{l}\text { Oligochaeta } \\
\text { Streblospio benedicti } \\
\text { Polydora ligni } \\
\text { Notomastus hemipodus }\end{array}$ & $\begin{array}{l}21.6 \\
11.9 \\
10.7 \\
10.0\end{array}$ & $\begin{array}{l}\text { Oligochaeta } \\
\text { Arabella iricolor } \\
\text { polydora ligni }\end{array}$ & $\begin{array}{l}25.7 \\
20.0 \\
12.4\end{array}$ \\
\hline Day 27 & $\begin{array}{l}\text { Streblospio benedicti } \\
\text { Oligochaeta } \\
\text { Polydora ligni }\end{array}$ & $\begin{array}{l}23.1 \\
21.9 \\
14.0\end{array}$ & $\begin{array}{l}\text { Streblospio benedicti } \\
\text { Oligochaeta } \\
\text { Polydora ligni }\end{array}$ & $\begin{array}{l}27.0 \\
21.2 \\
14.6\end{array}$ \\
\hline Day 127 & Spiochaetopterus oculatus & 11.3 & $\begin{array}{l}\text { Oligochaeta } \\
\text { Streblospio benedicti } \\
\text { Polydora ligni }\end{array}$ & $\begin{array}{l}17.9 \\
14.8 \\
16.5\end{array}$ \\
\hline Day 203 & Notomastus hemipodus & 14.5 & $\begin{array}{l}\text { Ampelisca abdita } \\
\text { Notomastus hemipodus } \\
\text { Exogone sp. }\end{array}$ & $\begin{array}{l}20.8 \\
18.1 \\
11.4\end{array}$ \\
\hline
\end{tabular}


Treatment HAL (H. wrightii planting), which developed no vegetative cover, was included in the unvegetated samples along with the 2 controls, CON (unplanted controls) and OS (undisturbed controls). Although this decision was made post hoc we feel this inclusion provides a useful addition to the results.

\section{Species Composition}

Numerically, the most important taxon throughout the study was the Polychaeta (Table 1). At the start of the experiment and in the Day 27 samples similar abundances of this group were observed in all treatment plots, with mean contribution of $67 \%$ (range 58.6 to $73.7 \%$ ) and $70 \%$ (range 60.5 to $75.0 \%$ ) to numerical abundance in the vegetated and unvegetated samples, respectively. Two spionid polychaetes, Streblos-

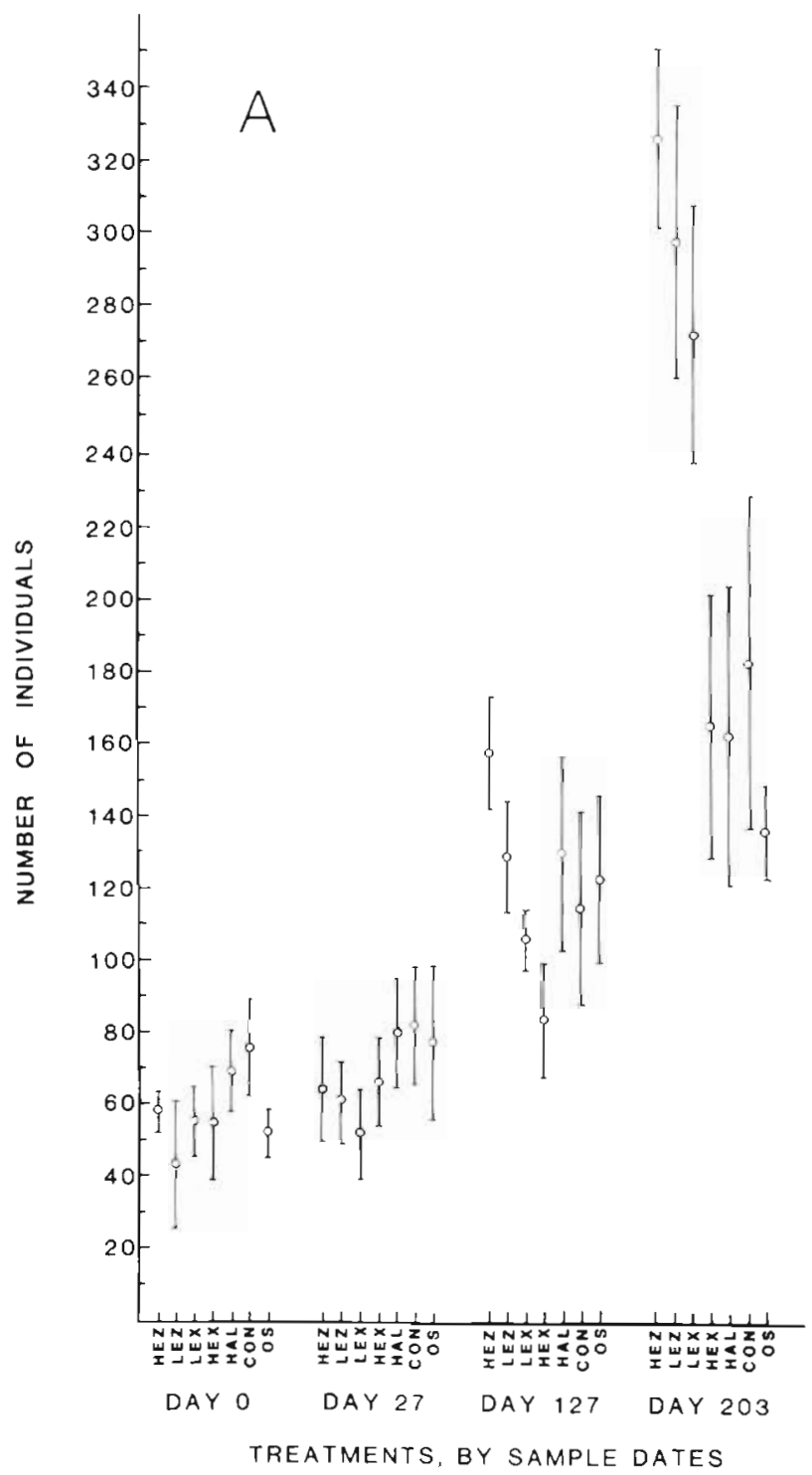

pio benediciti and Polydora ligni, and unidentified oligochaetes were the most abundant species in the Day 0 and Day 27 samples. S. benedicti, P. ligni, and the Oligochaeta continued to dominate the Day 127 unvegetated samples. No one species dominated in the vegetated treatments in the Day 127 samples. Only 1 species, the chaetopterid polychaete Spiochaetopterus oculatus contributed more than $10 \%$ to total numerical abundance. Other species were numerically important in the Day 127 samples, but no one species among these other taxonomic groups comprised more than $10 \%$ of the total number of individuals. In both the vegetated and unvegetated treatment plots, gastropods (14.2\% and $7.3 \%$ ), bivalves (16.2\% and $11.3 \%$ ), and amphipods $(24.7 \%$ and $12.2 \%)$ were frequently encountered.

The differences in species composition and dominance noted in the February samples became more

Fig. 3. (A) Mean and standard deviation for number of individuals sample ${ }^{-1}$. All treatments grouped by sampling date. HEZ (High Energy $Z$. marina), LEZ (Low Energy Z. marina), HEX (High Energy Z. marina in Mix with Halodule wrightlin), LEX (Low Energy $Z$. marina in Mix with $H$. wrightil), HAL ( $H$. wrightii), OS (Outside), and CON (Control). (B) Mean and standard deviation for number of taxa per sample. All treatments grouped by sampling dates. HEZ (High Energy $Z$. marina), LEZ (Low Energy Z. marina), HEX (High Energy $Z$. marina in Mix with $H$. wrightin), LEX (Low Energy $Z$. marina in Mix with $H$. wrightil), HAL (H. wrightil), OS (Outside), and CON (Control)

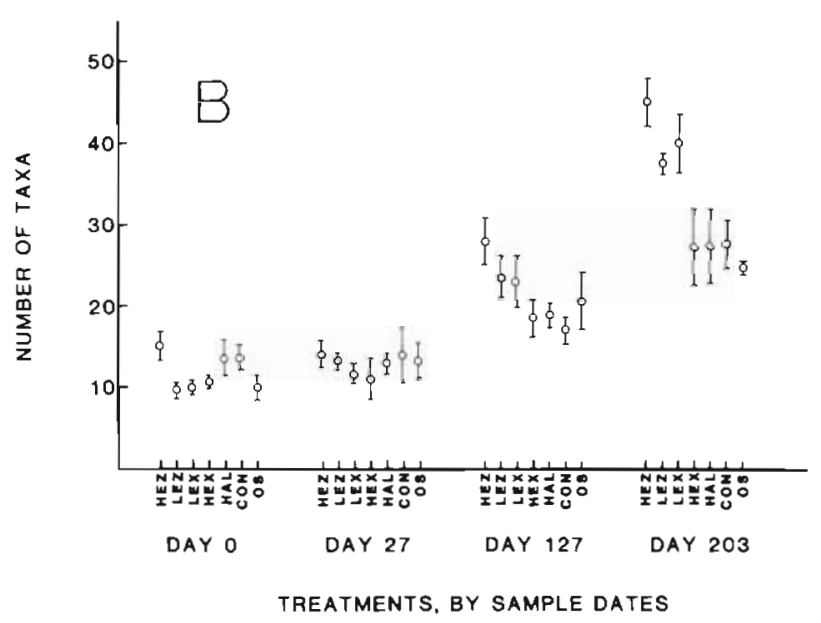


pronounced in the Day 203 samples as eelgrass density and biomass increased. Polychaetes continued to dominate both the vegetated (40.9\%) and the unvegetated $(47.4 \%)$ treatments but with new families, such as syllids and capitellids, replacing the spionids, the fall dominants. Amphipods, with Ampelisca abdita the most numerous, were the second most abundant group in both the vegetated and unvegetated treatments, with $35.1 \%$ and $33.2 \%$, respectively, of the total number of individuals belonging to this group. Gastropods and bivalves persisted to the end of the experiment in the vegetated treatments $(11.7 \%$ and $9.6 \%$, respectively) but were either found in insignificant numbers or were absent in the unvegetated treatments.

\section{Community Parameters}

The average density ( $N$ ) and species numbers (S) increased relative to initial $\mathrm{N}$ and $\mathrm{S}$ values in all treatments and controls by the end of the 203 monitoring period (Fig. 3). Average density (N) and number of species (S) among the treatments for each sampling period (one-way ANOVA, $\alpha=0.05$ ) showed small but significant differences in the pre-planting samples, no differences among treatments in the Day 27 samples, and highly significant differences ( $P<0.005$ ) among treatments in both the Day 127 and Day 203 samples. Factorial ANOVA ( $\alpha=0.05)$, with 2 sampling times as blocks and 7 treatments within each block, revealed that time, treatment, and an interaction of time with treatment significantly affected the density and the number of species collected during the experiment (Table 2). Dominance values calculated for the collection were affected by sampling date and an interaction of date with treatment. The diversity of the collection was affected only by sampling date.

Analysis of the ANOVA results by Duncan's Test (Fig. 4) identified differences in mean number of indi-

Table 2. Analysis of variance of community parameters, with sampling dates as blocks and transplant treatments and controls as treatments

\begin{tabular}{|c|c|c|c|}
\hline & $\begin{array}{c}\text { Date } \\
\text { F Values }\end{array}$ & $\begin{array}{c}\text { Treatment } \\
\text { F values }\end{array}$ & $\begin{array}{c}\text { Interaction } \\
\text { (Date X TMT) } \\
\text { F Values }\end{array}$ \\
\hline Density & $303.6^{\cdots}$ & $13.2 \cdots$ & $13.0^{\cdots}$ \\
\hline $\begin{array}{l}\text { Number of } \\
\text { Taxa }\end{array}$ & $358.4^{\cdots}$ & $20.3 \cdots$ & $8.1^{\cdots}$ \\
\hline Diversity & $29.4 \cdots$ & 3.5 & 3.4 \\
\hline Dominance & $13.9^{\cdots}$ & 3.2 & $6.0^{\circ}$ \\
\hline \multicolumn{4}{|c|}{$\begin{array}{l}\text { - Significant at the } 95 \% \text { level } \\
\text { - Significant at the } 99 \% \text { level } \\
\text {.. Significant at the } 99.9 \% \text { level }\end{array}$} \\
\hline
\end{tabular}

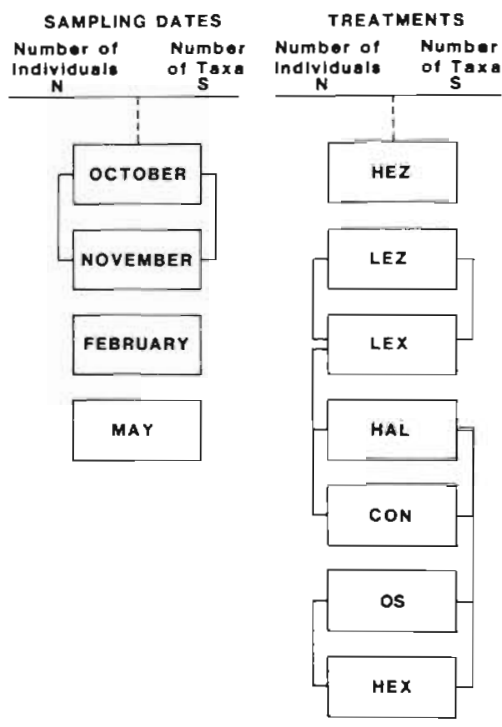

Fig. 4. Diagram of results of Duncan's multiple range test: lines connect treatments not significantly different ( $\alpha=0.05$ ). Right hand lines indicate similarities in number of taxa; left hand lines, similarities in number of individuals. Unique treatments stand alone. HEZ (High Energy Z. marina), LEZ (Low Energy $Z$. marina), HEX (High Energy $Z$. marina in Mix with $H$. wrightii), LEX (Low Energy $Z$. marina in Mix with $H$. wrightil), HAL ( $H$. wrightil), OS (Undisturbed Control), and CON (Planting Control)

viduals and number of species among sampling dates and treatments. Transplant treatments that developed seagrass cover (treatments HEZ, LEZ, and LEX) differed in macrofaunal density and number of species from the controls (CON, OS) and the unsuccessful transplant treatments (HAL, HEX). Faunal collections sampled late in the experiment (February - Day 127, May - Day 203) differed markedly from earlier samples in all community parameters.

The significant effect of treatment on density and numbers of species suggested that eelgrass shoot density may be related to the changes in these parameters observed during the experiment. We plotted regressions of the 4 descriptors calculated for our macrofaunal collections, numerical abundance, number of taxa, species diversity, and dominance on the eelgrass shoot densities observed in all treatments (Fig. 5). The result was a model with the regression lines described by asymptotic equations where the number of individuals $\left(\mathrm{r}^{2}=0.89\right)$, number of taxa $\left(\mathrm{r}^{2}=0.92\right)$, and diversity $\left(\mathrm{r}^{2}=0.82\right)$ displayed strong positive correlations with shoot density. Dominance $\left(r^{2}=-0.60\right)$, on the other hand, displayed a weak negative asymptotic relation to eelgrass density. At higher shoot densities $(\geq 300$ ) the number of individuals, the number of taxa and the diversity of the collection appear to remain unchanged.

We plotted a series of lines regressing community 

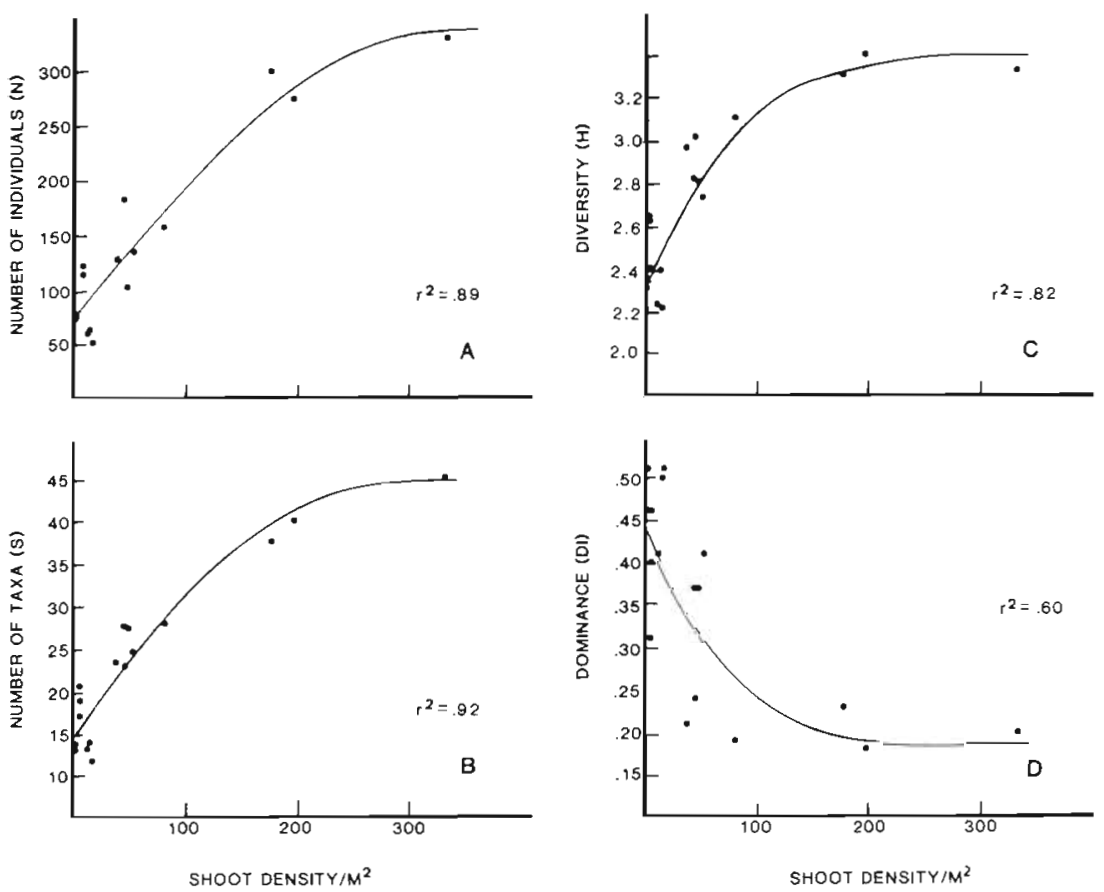

Fig. 5. Regressions of community parameters in an artificially established seagrass bed as function of density of Zostera marina shoots, with coefficients of determination. (A) Number of individuals; (B) number of taxa; (C) diversity; (D) dominance

descriptors on time for treatments without vegetative cover (Fig. 6) and for those with vegetative cover (Fig. $7)$. The mean number of individuals, species, and diversity observed in the unvegetated treatments (Fig. 6) increased linearly through time, with $\mathrm{I}^{2}$ values of
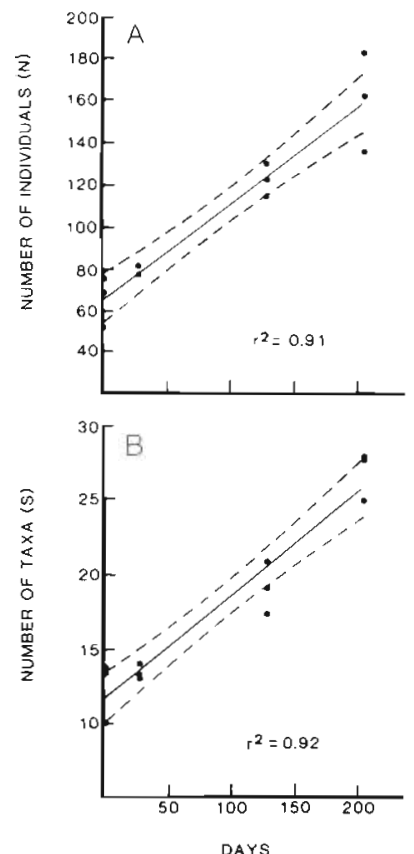

Fig. 6. Regressions of community parameters for unvegetated samples in an artificially established seagrass bed as function of time, with $95 \%$ confidence limits and coefficients of determination. (A) Number of individuals; (B) number of taxa; (C) diversity
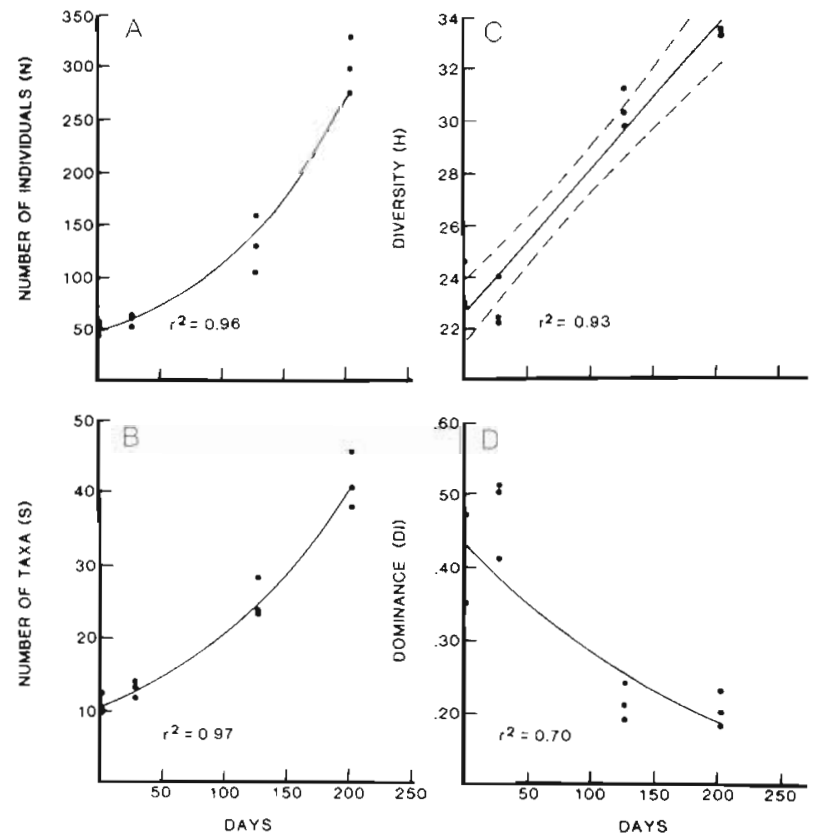

Fig. 7. Regressions of community parameters for vegetated samples in an artificially established seagrass bed as function of time with coefficients determination. (A) Number of indi-

viduals; (B) number of taxa (C) diversity; (D) dominance

0.91, 0.92, and 0.63, respectively. Dominance in the unvegetated treatments displayed no significant changes through time. In the vegetated treatments (Fig. 7) both numerical abundance and number of species increased exponentially with $\mathrm{r}^{2}$ values of 0.96 and 0.97 . Dominance exponentially decreased through time $\left(\mathrm{r}^{2}=-0.70\right)$. Diversity in the vegetated treat- 
ments increased linearly $\left(\mathrm{r}^{2}=0.93\right)$ through time. Regression lines in the vegetated and unvegetated treatments were significantly different in slopes but not in intercepts (analysis of covariance, $\alpha=0.5$ ).

Indices of faunal affinity, a measure of the similarity in species composition between treatments, were calculated for the pre-planting samples and again at the end of the experiment (Table 3). October similarities

Table 3. Trellis diagrams of indices of faunal affinity (\% similarity) between treatments at the start of the experiment, Day 0 , and at the end, Day 203. Letters represent treatment plots. Treatment HEX not included

\begin{tabular}{|c|c|c|c|c|c|c|}
\hline \multicolumn{7}{|c|}{ (a) Day 0 samples } \\
\hline Treatment & HEZ & LEZ & LEX & HAL & CON & OS \\
\hline \multicolumn{2}{|l|}{ HEZ } & 64.1 & 51.1 & 41.5 & 69.4 & 58.7 \\
\hline \multicolumn{2}{|l|}{ LEZ } & & 42.3 & 38.4 & 59.8 & 65.2 \\
\hline \multicolumn{2}{|l|}{ LEX } & & & 46.9 & 58.5 & 51.4 \\
\hline \multicolumn{2}{|l|}{ HAL } & & & & 68.3 & 69.9 \\
\hline \multicolumn{2}{|l|}{$\mathrm{CON}$} & & & & & 72.1 \\
\hline \multicolumn{7}{|l|}{ OS } \\
\hline \multicolumn{7}{|c|}{ (b) Day 203 samples } \\
\hline Treatment & HEZ & LEZ & LEX & HAL & CON & OS \\
\hline \multicolumn{2}{|l|}{ HEZ } & 80.8 & 83.6 & 46.3 & 41.8 & 48.0 \\
\hline \multicolumn{2}{|l|}{ LEZ } & & 80.4 & 49.6 & 47.8 & 49.5 \\
\hline \multicolumn{2}{|l|}{ LEX } & & & 44.7 & 43.2 & 46.2 \\
\hline \multicolumn{2}{|l|}{ HAL } & & & & 81.0 & 76.0 \\
\hline \multicolumn{2}{|l|}{ CON } & & & & & 74.1 \\
\hline \multicolumn{2}{|l|}{ OS } & & & & & \\
\hline
\end{tabular}

(Day 0) among treatment plots ranged from $38 \%$ to $75 \%$, with average similarities greater than $50 \%$. Faunal affinities for the May samples (Day 203) were high within the vegetated ( 80 to $85 \%$ ) and unvegetated ( 74 to $81 \%$ ) treatment groups, while affinities between the groups remained at an average of less than $50 \%$.

\section{DISCUSSION}

To our knowledge, this experiment is the first to establish artificially a seagrass meadow with the goal of monitoring changes in selected physical, chemical, biological, and ecological factors during the development of the meadow. In addition to developing relatively simple and economical means of transplanting eelgrass, this innovative method also provides a new and useful experimental approach to the study of the structure and function of eelgrass macrofaunal communities.

Most previous studies of eelgrass communities were observational, involving simultaneous comparisons of vegetated and unvegetated areas (O'Gower and Wacasey, 1967 ; Santos and Simon, 1974; Stoner, 1980). Experimental denudation studies (Orth, 1977, Young and Young, 1978, Marshall and Lukas, 1970) have only suggested the role that seagrasses play in structuring benthic communities. Our experimental addition of varying densities of eelgrass directly demonstrates the contribution made by eelgrass to the development of the associated benthic community. In contrast, denudation studies can only indirectly assess the importance of eelgrass in benthic community studies.

Macrofauna collected from our artificially established eelgrass meadows appeared to be similar to the fauna reported from nearby established meadows. Macroinvertebrates in the most densely vegetated treatment (HEZ) were in excess of 4100 individuals $\mathrm{m}^{-2}$ in the Day 127 samples and 8500 individuals $\mathrm{m}^{-2}$ in the Day 203 samples, higher than the 900 individuals $\mathrm{m}^{-2}$ reported by Thayer et al. (1975b) in a year-long study of a grassbed in the nearby Newport River estuary. Stuart (unpubl. Ph. D. dissertation, North Carolina State University, in prep.) found densities of $5000 \mathrm{~m}^{-2}$ in an area adjacent to ours. Average macrofaunal densities in the unvegetated controls (CON) ranged from more than $1970 \mathrm{~m}^{-2}$ in preplanting samples to over $4790 \mathrm{~m}^{-2}$ in samples at the end of the experiment. These values were markedly higher than the average densities reported by Petrie, Price, and Thayer (unpubl. Annual Report to the Atomic Energy Commission, NMFS Atlantic Estuarine Fisheries Center, Beaufort, N. C., 1977) who observed between 420 and 920 individuals $\mathrm{m}^{-2}$ in unvegetated portions of the Newport estuary (Transects 4,5, and 6 of that study).

The use of a comparatively larger mesh screen in the Newport River studies (1.2 $\mathrm{mm}$ openings vs. $0.5 \mathrm{~mm}$ in our study) may have resulted in the loss of a significant number of small individuals. Lewis and Stoner (1980) found that only 51 to $57 \%$ of the fauna collected by a $0.5 \mathrm{~mm}$ screen was retained by a $1 \mathrm{~mm}$ mesh screen. Many of the dominant species found in that study, such as oligochaetes and spinoids, are small-bodied and may easily have passed through the larger mesh screen. The increased abundances we observed in the Day 127 and Day 203 samples were due to presence of large numbers of small juvenile forms that may have easily been lost through a $1.2 \mathrm{~mm}$ mesh.

The 89 taxa collected during this study was only 4 more than the number recorded by Thayer et al. (1975a), but considerably less than the 150 species observed by Stuart ( $P$ h. D. dissertation, North Carolina State University, in prep.). This discrepancy may be due to differences in the sampling devices used. Stuart, who used a box-Trap device, recovered many more epifaunal and cryptic species than were collected in our study. 
A graphic illustration of the effect the presence of eelgrass has on benthic community structure is provided by comparing plots of the regressions of numerical abundance and number of taxa on time for unvegetated and vegetated treatments (Figs. 6 and 7). Through the course of the experiment, from Fall through Spring, macrofaunal abundances and number of taxa collected increase linearly in the unvegetated treatments while exponential increases in these parameters occur in treatment plots with developing eelgrass cover. Diversity values, though initially similar in both vegetated and unvegetated plots, increase linearly at a greater rate in the vegetated treatments.

The high degree of faunal affinity within both the vegetated and unvegetated treatments, the lack of affinity between the 2 treatment groups, and the differences in dominant species after development of vegetative cover indicate that the composition of the fauna in the newly developed grassbed differed from the bare bottom fauna. While some investigators (e. $\mathrm{g}$. Santos and Simon, 1974; Kikuchi and Pérès, 1977) reported no changes in species composition between vegetated and unvegetated areas, most investigators (Heck and Wetstone, 1977; Stoner, 1980) have noted distinct differences in species composition, numerical abundance, and diversity between vegetated and unvegetated areas.

Several studies reported a relationship between the degree of vegetative cover, expressed either as biomass or shoot density, and values of certain descriptive community parameters. Several investigators noted that macrofaunal densities are higher in vegetated than in nearby unvegetated sites (O'Gower and Wacasey, 1967; Orth, 1973, 1975; Thayer et al. 1975a; Orth and Heck, 1980; Stoner, 1980). Hooks et al. (1976) and Heck and Orth (1980) demonstrated significant positive correlations between macrofaunal abundance and seagrass blade density. Similarly, Heck and Wetstone (1977) and Thorhaug and Roessler (1977) found that species composition and species richness of grassbed macroinvertebrates were related to macrophyte biomass. Several previous studies have directly or indirectly suggested that species abundances may not be linearly related to seagrass density. Brook (1978) established that at high Thalassia blade densities vegetative cover was not related to faunal abundance, while Orth $(1973,1977)$ and Stoner (1980) both noted decreases in species richness with increasing seagrass density. Our results support the suggested non-linear relation between grass density and macrofaunal density and number of species at high shoot densities. An asymptotic model describes more accurately the relationship. While there was a significant time and treatment interaction, the results of ANOVA and subsequent analysis by Duncan's Test indicate that increasing shoot density alone may be responsible for significant increases in the values of the community parameters we measurd.

The fourth parameter, dominance, displayed an overall asymptotic decrease with increasing grass cover, but with a much poorer fit of the regression line to the data. The initial decrease in dominance may reflect the reduction or loss of many of the dominant and ubiquitious benthic species (Boesch, 1973), many of which are infaunal tube-builders, a group whose presence may be inversely related to macrophyte biomass (Stoner, 1980). Increased surface area and increased complexity at high blade density may favor relatively few epiphytic, seagrass associated species (Heck and Wetstone, 1977; Thayer and Phillips, 1977; Stoner, 1980) which may result in increased dominance.

We have used our experimental transplant to study the role of seagrasses in structuring grassbed macrobenthic communities. We believe that our results contribute significantly to existing knowledge of the subject. More important though is the experimental technique we employed in this research.

There are relatively few manipulative studies of grassbed communities. The methods we have developed and employed in this study provide a new and promising avenue of research in this area. The technique is inexpensive, easily applied and, we believe, rewarding. We hope that it will find acceptance and use in the field, and serve to remedy the lack of experimental work in grassbed community ecology.

Acknowledgements. We extend thanks to the UNC Institute of Marine Sciences, Morehead City and to the Southeast Fisheries Center, NMFS, Beaufort Laboratory for their support during this study. We also thank Dr. H. W Paerl, Dr. C. H. Peterson, Dr G. W. Thayer, and H. H. Stuart for helpful comments and critical reviews of the manuscript. An anonymous referees' instructions on the judicious use of Occam's razor improved the manuscript. This research was supported by North Carolina Sea Grant 1-0-152-5220-REI53.

\section{LITERATURE CITED}

Adams, S. M. (1976). The ecology of eelgrass, Zostera marina (L.), fish communities. I. Structural analysis. J. exp. mar Biol. Ecol. 22: 269-291

Boesch, D. F. (1973). Classification and community structure of macrobenthos in Hampton Roads area, Virginia. Mar. Biol. 21: 226-244

Brett, C. E. (1963). Relationships between marine invertebrate infauna distribution and sediment type distribution in Bogue Sound, North Carolina. Ph. D. dissertation, University of North Carolina, Chapel Hill

Brook, I. M. (1978). Comparative macrofaunal abundance in turtlegrass Thalassia testudinum communities in South Florida characterized by high blade density. Bull. mar. Sci. 28: 212-217 
Cammen, L. M. (1976). Macroinvertebrate colonization of Spartina marshes artificially established on dredge spoil. Estuar. coast mar. Sci. 4: 357-372

Churchill, C. A., Cook, A. E., Riner, M. I. (1978). Stabilization of subtidal sediments by the transplantation of the seagrass Zostera marina L. New York Sea Grant Report, NYSSGP-R5-78-15

Connell, J. H. (1974). Field experiments in marine ecology In: Mariscal, R. (ed.) Experimental marine biology. Academic Press, New York, pp. 21-54

Dexter, R. W. (1944). Ecological significance of the disappearance of eelgrass at Cape Ann, Massachusetts. J. Wildl. Mgmt 8: 173-176

Dexter, R. W. (1950). Restoration of the Zostera faciation at Cape Ann, Massachusetts. Ecology 31: 286-288

Downing, J. A. (1979). Aggregation, transformation and design of benthos sampling programs. J. Fish. Res. Bd Can. 36: 1454-1463

Fauchald, K. (1977). The Polychaete worms, definitions and keys to the orders, families and genera. Natural History Museum of Los Angeles County, Science Series 28: 1-190

Fonseca, M. S. (1981). The interaction of a seagrass, Zostera marina L. with current flow, M. S. thesis, University of Virginia

Fonseca, M. S., Kenworthy, W. J., Homziak, J., Thayer, G. W. (1979). Transplanting of eelgrass and shoalgrass as a potential means of economically mitigating a recent loss of habitat. In: Cole, D. P. (ed.) Proceedings of the sixth annual conference on wetlands restoration and creation. Hillsborough Community College and Tampa Port Authority, Tampa, Florida, pp. 279-236

Heck, K. L., Jr., Orth, R. J. (1980). Structural components of eelgrass (Zostera marina) meadows in the lower Chesapeake Bay - Decapod crustacea. Estuaries 3: 289-295

Heck, K. L., Jr., Wetstone, G. S. (1977). Habitat complexity and invertebrate species richness and abundance in tropical seagrass meadows. J. Biogeography 4: 135-142

Hooks, T. A., Heck, K. L., Jr., Livingston, R. J. (1976). An inshore invertebrate community: structure and habitat associations in the northeastern Gulf of Mexico. Bull. mar Sci. 26: 99-109

Johnson, R. G. (1964). The community approach to paleoecology. In: Imbrie, T. Newell, N. (eds.) Approaches to paleoecology. Wiley, N. Y., pp. 107-134

Kenworthy, W. J. (1981). The interrelationship between seagrasses, Zostera marina and Halodule wrightii, and the physical and chemical properties of sediments in a midAtlantic coastal plain estuary near Beaufort, North Carolina (USA), M. S. thesis, University of Virginia

Kenworthy, W. J., Fonseca, M. S. (1977). Reciprocal transplant of the seagrass, Zostera marina L. effect of substrate on growth. Aquaculture 4: 161-176

Kenworthy, W. J., Fonseca, M. S., Homziak, J., Thayer, G. W. (1980). Development of a transplanted seagrass (Zostera marina L.) meadow in Back Sound, Carteret County, North Carolina. In: Cole, D. P. (ed.) Proceedings of the seventh annual conference on the restoration and creation of wetlands. Hillsborough Community College, Environmental Studies Center, in cooperation with Tampa, Florida, pp. 175-194

Kikuchi, T. (1974). Japanese contribution on consumer ecology in eelgrass (Zostera marina $L$.) beds with special reference to trophic relationship and resources in inshore fisheries. Aquaculture 4: 145-160

Kikuchi, T., Pérès, J. M. (1977). Animal communities in seagrass beds: a review. In: Mcroy, C. P., Helfferich, C. (eds.)
Seagrass ecosystems: a scientific perspective. Marcel Dekker, New York, pp. 147-193

Lewis, F. G. III Stoner, A. W. (1980). An examination of methods for sampling macrobenthos in seagrass meadows. Bull. mar. Sci. 31: 116-124

Lindall, W. N., Mager, A., Thayer, G. W., Ekberg, D. R. (1979) Estuarine habitat mitigation planning in the Southeast. In: Swanson, G. A. (ed.) The mitigation symposium. Rocky Mountain Forest and Range Experiment Station, Forest Service, U. S. Department of Agriculutre. Fort Collins, Colorado, pp. 129-135

Linton, T L., Cooper, A. W. (1971). Damaged estuarine ecosystems, their restoration and recovery. ASB Bull. 18: 129-136

Marshall, N., Lukas, K. (1970). Preliminary observations on the properties of bottom sediments with and without eelgrass, Zostera marina, cover. Proc. natn. Shelfish Ass. 60: 107-111

Mason, W. T., Yevich, P. P. (1967). The use of phloxine B and rose bengal to facilitate sorting benthic samples. Trans. Am. microsc. Soc. 86: 221-223

McNaughton, J. J. (1967). Relationship among functional properties of California grasslands. Nature, Lond. 216 $168-169$

McRoy, C. P. (1974). Seagrass productivity: carbon uptake experiments in eelgrass, Zostera marina. Aquaculture 4: 131-137

McRoy, C. P., Goering, J. J. (1974). Nutrient transfer between the seagrass Zostera marina and its epiphytes. Nature, Lond. 248: 173-174

Murdoch, W. W., Evans, F. C., Peterson, C. H. (1972). Diversity and pattern in plants and insects. Ecology 53: 819-828

O'Gower, A. K., Wacasey, J. W. (1967). Animal communities associated with Thalassia, Diplanthera, and sand beds in Biscayne Bay. II. Analysis of communities in relation to water movement. Bull. mar. Sci. 17: 175-210

Orth, R. J. (1973). The benthic infauna of eelgrass, Zostera marina, beds. Chesapeake Sci. 14: 258-269

Orth, R. J. (1974). The effect of tropical storm Agnes on the benthic fauna of eelgrass, Zostera marina, in the lower Chesapeake Bay. In: Davis, J. (ed.) The effects of tropical storm Agnes on the Chesapeake Bay estuarine system. Chesapeake Research Consortium Publ. 34 (Abstr.)

Orth, R. J. (1975). Destruction of eelgrass, Zostera marina, by the cownose ray, Rhinoptera bonasus, in the Chesapeake Bay. Chesapeake Sci. 16: 205-208

Orth, R. J. (1975). The importance of sediment stability in seagrass communities. In: Coull, B. C. (ed.) Ecology of marine benthos. University of South Carolina Press, Columbia, S. C., pp. 281-300

Orth, R. J., Heck, K. L., Jr. (1980). Structural components of eelgrass (Zostera marina) meadows in lower Chesapeake Bay-Fishes. Estuaries 3: 278-288

Penhale, P. (1977). Macrophyte-epiphyte biomass and productivity in an eelgrass (Zostera marina L.) community. J. exp. mar. biol. 26: 211-224

Petersen, C. J. G. (1918). The sea bottom and its production of fish food. A survey of the work done in connection with the valuation of the Danish waters from 1883-1917. Rep. Dan. Biol. Stn 25: 1-82

Phillips, R. C. (1974a). Temperate grass flats. In: Odum, H. T., Copeland, B. J., McMahan, E. A. (eds.) Coastal ecological systems of the United States: a source book for estuarine planning, Vol. 2. Conservation Foundation, Washington, D. C., pp. 244-299

Phillips, R. C. (1974b). Transplantation of seagrasses with 
special emphasis on eelgrass, Zostera marina. Aquaculture 4: 161-176

Phillips, R. C. (1976). Preliminary observations on transplanting and a phenological index of seagrass. Aquat. Bot. 2: 93-101

Phillips, R. C., McRoy, C. P. (1980). Handbook of seagrass biology, Garland Press, New York

Ranwell, D. S., Wyer, D. W., Boorman, L. A, Pizzey, J. M., Waters, R. J. (1974). Zostera transplants in Norfolk and Suffolk, Great Britian. Aquaculture 4: 185-198

Rasmussen, E. (1973). Systematics and ecology of the Isefjord marine fauna (Denmark). Ophelia 11: 1-507

Robilliard, G. A., Porter, P. E. (1976). Transplantation of eelgrass (Zostera marina) in San Diego Bay. Consultation for U. S. Naval Undersea Center, NUC TN 1701

Sanders, H. L. (1960). Benthic studies in Buzzard's Bay. II. The structure of the soft-bottom community. Limnol. Oceanogr. 5: 138-153

Santos, S. L., Simon, J. L. (1974). Distribution and abundance of the polychaetous annelids in a South Florida estuary. Bull. mar. Sci. 24: 669-689

Sokal, R. R., Rohlf, F. J. (1969). Biometry, Freeman, San Francisco

Steel. R. G. D., Torrie, J. H. (1960). Principles and procedures in statistics, McGraw-Hill, New York

Stoner, A. W (1980). The role of seagrass biomass in the organization of benthic macrofaunal assemblages. Bull. mar. Sci. 30: 538-551

Thayer, G. W., Stuart, H. H. (1974). The bay scallop makes its bed of seagrass. U. S. Natl. Mar Fish. Serv., Mar Fish. Rev. 36 (7): $27-30$
Thayer, G. W., Wolfe, D. A., Williams, R. B. (1975a). The impact of man on seagrass systems. Am. Scient. 63: $288-296$

Thayer, G. W., Adams, S. M., LaCroix, M. W (1975b). Structural and functional aspects of a recently established $Z_{0}$ stera marina community. In: Cronin, L. E. (ed.) Estuarine research, Vol. 1 Academic Press, N. Y., pp. 518-540

Thayer, G. W., Phillips, R. C. (1977). Importance of eelgrass beds in Puget Sound. U. S. Natl. Mar Fish. Serv., Mar Fish Rev. 39 (11): 18-22

Thorhaug, A., Roessler, M. A. (1977). Seagrass community dynamics in a subtropical estuarine lagoon. Aquaculture 12: $253-277$

Wayne, C. J. (1974). Effect of artificial seagrass on wave energy and nearshore sand transport. (Abstr.). Bull. Am Ass. Petrol. Geol. 58: 2214

Wood, E. J. F., Odum, W. E., Zieman, J. C. (1969). Influence of seagrasses on the productivity of coastal lagoons. Lagunas Costeras. Un Simposio Mem. Simp. Intern. UNAMUNESCO, Mexicol, D. F., Nov. 1967, pp. 495-502

Young, D. K., Young, M. W. (1978). Regulation of species densities of seagrass-associated macrobenthos: evidence from field experiments in the Indian River estuary. Florida. J. mar Res. 36: 569-593

Zieman, J. G., Wetzel, R. G. (1980). Productivity in seagrasses: methods and rates. In: Phillips, R. C., McRoy, C. P. (eds.) Handbook of seagrass biology: an ecosystem perspective Garland Press, New York, pp. 87-116

This paper was submitted to the editor; it was accepted for printing on May 8, 1982 